\title{
PENERAPAN APLIKASI MOBILE UNTUK PELAPORAN KINERJA PEGAWAI DALAM MENDUKUNG $e$-GOVERNMENT
}

\section{THE UTILIZATION OF MOBILE APPLICATION AS EMPLOYEES PERFORMANCE REPORT IN SUPPORTING Q-GOVERNMENT}

\author{
Maulidatur Rohmah ${ }^{1}$ dan Eriyanto ${ }^{2}$ \\ ${ }^{1,2}$ Pascasarjana Ilmu Komunikasi, FISIP Universitas Indonesia \\ Kampus UI Salemba, Gedung IASTH Lantai 6 \\ Jl. Salemba Raya No. 4, Jakarta 10430 \\ maulidatur.rhm@gmail.com
}

Diterima : 18 September 2019

Direvisi : 16 Oktober 2019

Disetujui : 27 Januari 2020

\begin{abstract}
e-Visum is a mobile performance report application to implement e-government concepts. The purpose of the application built by BKKBN and an app developer is to report the daily activities of Keluarga Berencana $(K B)$ instructors more easily, effectively, efficiently, and in realtime. This study aims to analyze the possible impact of e-Visum development with third party involvement, along with the adoption rate by KB instructors in various provinces. This study used a qualitative approach with case study method. The data were collected through semi-structured interviews and e-Visum filling report. Based on the interviews, it was found that the development of e-Visum has brought many positive impacts both for KB instructors or $B K K B N$, but there were also negative impacts that should be anticipated about data security and confidentiality. The results showed that e-Visum utilization has increased from 64,8\% in January to 75,09\% in September 2018. The length of time required was an important factor in the innovation adoption process. Based on the rate of adoption, East Java fell into innovator category, while North Maluku, Papua, and West Papua were categorized in laggard category.
\end{abstract}

Keywords: e-Visum, Innovation Diffusion, e-Government

\begin{abstract}
ABSTRAK
e-Visum merupakan aplikasi mobile pelaporan kinerja pegawai untuk mendukung penerapan e-government. Tujuan dari aplikasi yang dibangun oleh BKKBN bersama pihak ketiga ini adalah agar para penyuluh Keluarga Berencana (KB) di daerah dapat melaporkan kegiatan hariannya dengan lebih mudah, efektif, efisien, dan secara real time. Penelitian ini bertujuan untuk menganalisis dampak dari pengembangan aplikasi kinerja mobile pegawai dengan adanya keterlibatan pihak ketiga, serta mengetahui bagaimana tingkat adopsi para penyuluh KB di berbagai provinsi dalam memanfaatkan e-Visum sebagai aplikasi pelaporan kinerja mereka. Penelitian ini menggunakan pendekatan kualitatif dengan metode studi kasus. Teknik pengumpulan data dilakukan melalui wawancara semi terstruktur dan laporan pengisian e-Visum sebagai pengumpulan data sekunder. Berdasarkan hasil wawancara, diketahui bahwa pengembangan aplikasi e-Visum memiliki dampak positif bagi penyuluh KB maupun BKKBN, namun ada juga dampak negatif yang harus diperhatikan terkait dengan faktor keamanan dan kerahasiaan data. Hasil analisa data laporan pengisian e-Visum menunjukkan adanya peningkatan dalam pemanfaatan aplikasi kinerja mobile e-Visum oleh penyuluh KB, yaitu dari 64,8\% di bulan Januari menjadi 75,09\% pada bulan September 2018. Lamanya waktu yang dibutuhkan menjadi faktor penting dalam sebuah proses adopsi inovasi. Berdasarkan kecepatan waktu adopsinya, Jawa Timur masuk dalam kategori inovator, sedangkan Maluku Utara, Papua dan Papua Barat masuk ke dalam kategori lamban.
\end{abstract}

Kata Kunci: e-Visum, Difusi Inovasi, e-Government 


\section{PENDAHULUAN}

Perkembangan teknologi informasi dan komunikasi mengakibatkan pergeseran penggunaan media dari yang semula analog menjadi digital. Hal ini sejalan dengan pertumbuhan pengguna internet dan media sosial yang meningkat drastis dari tahun ke tahun. Berdasarkan data yang dirilis oleh www.wearesocial.com, pada tahun 2019 tercatat jumlah pengguna mobile mencapai 355,5 juta dari total populasi penduduk 268,2 juta jiwa (Kemp, 2019). Artinya, seorang individu ada yang memiliki lebih dari satu mobile phone. Pengguna internet di Indonesia juga mengalami peningkatan $13 \%$ dari data tahun 2018. Data ini menunjukkan bahwa masyarakat Indonesia sudah semakin familiar dengan teknologi komunikasi dan pemanfaatan jaringan internet. Smartphone menjadi infrastruktur penunjang yang paling banyak digunakan untuk mengakses jaringan internet, yaitu sebesar 60\% (Kemp, 2019).

Dalam beberapa dekade terakhir, perkembangan teknologi komunikasi telah memunculkan media baru yang dinamakan media digital. Digitalisasi tersebut telah mengubah gaya hidup dan perilaku, baik individu, kelompok, maupun organisasi (Meranti \& Irwansyah, 2018). Peluang ini dipergunakan juga oleh organisasi pemerintah yang mulai memanfaatkan teknologi dalam pengelolaan organisasinya. Salah satunya adalah melalui pengembangan aplikasi kepemerintahan untuk menunjang tugas dan fungsi pegawai, yang sering disebut dengan $e$ government. Hampir semua lembaga pemerintah, khususnya di Indonesia, telah mulai menerapkan e-government.

Proses birokrasi yang panjang dan berbelit, terutama di sektor pelayanan publik mampu diatasi dengan memanfaatkan teknologi ke dalam proses administrasinya, misalnya inovasi layanan kesehatan melalui $e$ Health milik pemerintah Kota Surabaya. Selain mampu menghilangkan sistem antrian pasien secara fisik, $e$-Health juga telah terintegrasi dengan data kependudukan dan informasi pasien di puskesmas/rumah sakit di Kota Surabaya sehingga pelayanan kesehatan menjadi lebih efisien (Putra, 2016). Selain di sektor pelayanan publik, organisasi pemerintah juga telah menggunakan media digital dalam pengelolaan internal organisasi. Peralihan dari pelaporan kinerja manual menjadi pelaporan digital merupakan bentuk pemanfaatan teknologi informasi untuk meningkatkan efektivitas dan efisiensi operasional program pemerintah.

Badan Kependudukan dan Keluarga Berencana Nasional atau yang disingkat BKKBN, selaku lembaga nonkementerian yang berwenang dalam bidang pengendalian penduduk dan keluarga berencana juga secara perlahan menerapkan konsep e-government dalam mengelola internal organisasinya. Salah satunya adalah dengan membangun aplikasi eVisum, yaitu aplikasi mobile untuk pelaporan kinerja bagi para penyuluh keluaga berencana yang tersebar di daerah. Aplikasi e-Visum penyuluh KB dapat diunduh di Google Play Store melalui fasilitas smartphone android yang dimiliki oleh para penyuluh tersebut. Dengan memasukkan aplikasi e-Visum ke Google Play Store, para penyuluh KB yang tersebar di seluruh desa di Indonesia dapat dengan mudah mengunduhnya untuk kemudian menggunakannya sebagai media pelaporan, pencatatan dan pengumpulan data secara online.

Penggunaan teknologi dalam pemerintahan (e-government) menarik untuk dikaji. Pengembangan sistem digital dalam 
pemerintahan menjadi sebuah target yang harus direalisasikan oleh tiap lembaga pemerintah. Dalam pembuatan aplikasi mobile, lembaga pemerintah seringkali menggunakan jasa pihak ketiga selaku pengembang atau vendor karena keterbatasan sumber daya internal. Fokus penelitian ini adalah mengenai aplikasi e-Visum BKKBN yang melibatkan pihak ketiga dalam pengembangannya serta pemanfaatan e-Visum sebagai aplikasi pelaporan kinerja oleh para penyuluh KB. Oleh karena itu, penelitian ini bertujuan untuk mengetahui dampak yang mungkin terjadi dengan adanya keterlibatan pihak ketiga dalam pengembangan aplikasi e-Visum dan mengetahui bagaimana tingkat adopsi para penyuluh KB dalam memanfaatkan aplikasi eVisum sebagai aplikasi pelaporan kinerja mereka ditinjau dari teori difusi inovasi. Hasil penelitian ini secara praktis diharapkan dapat menjadi masukan dan pertimbangan bagi lembaga pemerintah yang mulai menerapkan konsep e-government dalam pengelolaan organisasinya, baik di internal maupun eksternal.

Berbagai aplikasi telah dibangun dan dikembangkan oleh BKKBN untuk meningkatkan efektivitas dan efisiensi pengelolaan program, salah satunya adalah eVisum. Aplikasi ini menyediakan laporan kinerja mobile bagi para penyuluh keluarga berencana. Disebut mobile karena aplikasi ini dapat dioperasikan melalui fasilitas smartphone android yang dimilikinya dan bisa digunakan di mana saja mereka berada (Thulin \& Vilhelmson, 2007). Aplikasi e-Visum ini dikembangkan oleh BKKBN pada tahun 2017 bekerja sama dengan pihak ketiga selaku pengembang aplikasi atau vendor yang telah memenuhi kualifikasi. Aplikasi kinerja mobile ini secara resmi digunakan pada tanggal 1
Januari 2018. Aplikasi e-Visum berisi datadata penyuluh KB dan laporan hasil kegiatan yang dilakukan tiap harinya. Aplikasi ini memiliki fitur beranda, kegiatan, pengumuman, dan profil. Aplikasi e-Visum terus mengalami pengembangan dengan menambahkan fitur-fitur dan tampilan baru yang lebih baik dan mendukung analisis kinerja penyuluh $\mathrm{KB}$ dan pembaharuan terakhirnya adalah e-Visum versi 3.0. Berdasarkan Peraturan Kepala Badan Kependudukan dan Keluarga Berencana Nasional Nomor 22 Tahun 2017 dan Petunjuk Teknis Pelaksanaan e-Visum, ada 2 (dua) kategori kegiatan yang harus dijalankan oleh para penyuluh KB di lapangan, yaitu kegiatan penyuluhan dan nonpenyuluhan. Penyuluhan merupakan kegiatan penyampaian komunikasi, informasi dan edukasi (KIE) program kependudukan, $\mathrm{KB}$ dan pembangunan keluarga (KKBPK) dalam upaya meningkatkan pengetahuan, sikap dan perilaku individu, keluarga dan atau masyarakat (baik KIE perseorangan maupun kelompok). Adapun kegiatan nonpenyuluhan umumnya bersifat administratif, rutinitas, koordinasi dan pengembangan serta kegiatan lainnya dalam pelaksanaan program KKBPK (BKKBN, 2017).

Menurut data SIMSDM (Sistem Informasi Manajemen Sumber Daya Manusia) Biro Kepegawaian BKKBN per tanggal 1 Oktober 2018, jumlah tenaga penyuluh $\mathrm{KB}$ yang tersebar di seluruh Indonesia ada sebanyak 14.758 orang. Para penyuluh tersebut harus melaporkan detil kegiatan hariannya secara online beserta titik koordinat lokasi kerjanya. Menurut Clare and Loucopoulos (1987), informasi merupakan hasil dari pemrosesan data yang bermakna. Jadi, data tersebut haruslah faktual, artinya 
dihasilkan dari rekaman peristiwa yang terukur dan eksplisit (Checkland and Holwell, 1998). Data yang dimasukkan ke dalam aplikasi eVisum nantinya akan digunakan untuk memantau dan menilai kinerja para penyuluh KB. Hasil penilaian itu akan berimplikasi terhadap besaran tunjangan kinerja yang diterimanya setiap bulan.

Menurut Rogers (1995), difusi merupakan sebuah proses mengomunikasikan sebuah inovasi melalui saluran tertentu sepanjang waktu kepada anggota sistem sosial. Ada empat elemen utama difusi inovasi (Lehmann, 2007). Pertama, inovasi yaitu ide, karya, atau objek yang dianggap baru oleh seseorang. Kedua, komunikasi yakni proses penyusunan dan penyampaian pesan oleh pelaku yang terlibat kepada orang lain dengan tujuan untuk mencapai pemahaman yang sama. Ketiga, waktu adopsi. Ini merujuk pada kecepatan relatif anggota-anggota sistem sosial untuk mengadopsi sebuah inovasi. Keempat, sistem sosial. Difusi inovasi dipengaruhi oleh struktur sosial, sebaliknya difusi inovasi juga memengaruhi pola struktur sosial dalam suatu sistem sosial.

Gabriel Tarde sebelumnya juga telah memperkenalkan kurva difusi yang berbentuk S (atau S-shaped diffusion curve), yang menggambarkan bahwa sebuah inovasi yang dilakukan oleh seseorang mempunyai kaitan dengan dimensi waktu. Kurva itu juga memiliki dua buah sumbu utama yaitu dimensi waktu dan tingkat adopsi. Teori difusi inovasi menjelaskan tentang bagaimana sebuah inovasi baru (ide/gagasan, ilmu pengetahuan dan teknologi) dikomunikasikan pada sebuah kultur masyarakat dan dimungkinkan untuk diadopsi oleh individu atau suatu kelompok sosial tertentu. Tingkat adopsi individu terhadap sebuah inovasi baru memiliki kecepatan yang berbeda-beda meskipun mereka berada dalam sebuah lingkungan atau sistem sosial yang sama. Berdasarkan kecepatan dan sikap terhadap sebuah inovasi, individu dapat dibagi ke dalam lima tingkatan (Rogers, 2003). Pertama, inovator, yakni individu yang pertama kali mengadopsi inovasi. Individu kategori ini dicirikan dengan keberaniannya dalam mengambil risiko, mobile, cerdas, dan memiliki kemampuan ekonomi yang tinggi. Kedua, perintis/pelopor (Early Adopters). Individu kategori ini menjadi perintis dalam penerimaan inovasi. Ketiga, pengikut dini (Early Majority). Kategori ini umumnya penuh pertimbangan dan akan melihat sekitarnya terlebih dahulu sebelum melakukan adopsi. Keempat, pengikut akhir (Late Majority). Individu yang masuk kategori ini menjadi pengikut akhir dalam penerimaan inovasi. Terakhir adalah kelompok lamban/kolot (Laggard). Individu yang masuk kategori ini disebut memiliki wawasan yang terbatas, bukan opinion leader dan mempunyai sumber daya yang terbatas juga.

Karakteristik inovasi yang dirasakan oleh individu menjelaskan tingkat adopsi yang berbeda-beda. Ada 5 (lima) karakteristik yang menentukan tingkat adopsi individu atau sistem sosial tertentu terhadap sebuah inovasi, yaitu keuntungan relatif, kesesuaian, kompleksitas, kemampuan uji coba (trialability) dan observability (Rogers, 2003). Pertama, keuntungan relatif adalah sejauh mana inovasi dianggap lebih baik daripada sebelumnya. Ukurannya biasanya melalui keuntungan secara ekonomi, tingkat kepuasan dan kebanggaan yang diperoleh oleh seseorang. Karakteristik kedua adalah kesesuaian, yakni tingkat konsistensi sebuah inovasi dengan nilai-nilai yang ada pada 
seseorang, pengalaman masa lalu dan kebutuhannya. Karakteristik ketiga yaitu kompleksitas, yakni tingkat kesulitan seorang individu untuk memahami dan menggunakan sebuah inovasi. Karakteristik keempat yaitu trialability, yakni tingkat uji coba suatu inovasi secara terbatas. Karakteristik kelima yakni observability, yaitu tingkat kemudahan sebuah hasil inovasi untuk terlihat oleh orang lain. Makin mudah seseorang untuk melihat hasil positif dari sebuah inovasi, makin besar kemungkinan tingkat adopsinya. Inovasi yang memiliki keuntungan, kesesuaian, trialability dan observability lebih besar serta kompleksitas yang lebih sedikit akan lebih cepat diadaptasi oleh individu (Rogers, 2003).

\section{METODOLOGI PENELITIAN}

Penelitian ini menggunakan pendekatan kualitatif untuk menjelaskan tingkat adopsi penyuluh KB terhadap aplikasi e-Visum serta menganalisis dampak pengembangan aplikasi tersebut. Pendekatan kualitatif bersifat induktif yaitu berorientasi pada penemuan dan proses, memiliki validitas tinggi, kurang peduli dengan kemampuan menggeneralisasi, dan lebih fokus menggali pemahaman yang lebih dalam tentang masalah penelitian dalam konteks tertentu (Ulin, Robinson \& Tolley, 2004). Penelitian kualitatif menghasilkan temuan tanpa melalui prosedur statistik atau cara-cara kuantifikasi lainnya (Strauss \& Corbin, 1990), namun berupaya memahami kompleksitas dunia melalui pengalaman para peserta (Tuli, 2010). Penelitian dilakukan pada instansi BKKBN karena di awal tahun 2017 terjadi peralihan status penyuluh $\mathrm{KB}$ dari pegawai daerah menjadi pegawai pusat. Peralihan ini tentu berdampak pada peralihan kebijakan yang harus mereka ikuti, termasuk peralihan dari sistem pelaporan manual di daerah menjadi pelaporan kinerja mobile melalui aplikasi e-Visum.

Metode yang dipakai adalah studi kasus. Teknik pengumpulan data yang digunakan adalah wawancara dan data sekunder. Dalam melakukan wawancara, penulis menggunakan teknik semiterstruktur. Teknik ini mengharuskan penulis membuat serangkaian daftar pertanyaan yang telah dirancang untuk menggali informasi semaksimal mungkin (Langridge, 2007). Menurut Langridge (2007), teknik semiterstruktur merupakan perpaduan dari konsistensi dan fleksibilitas yang paling dapat memenuhi kebutuhan peneliti. Informan dalam penelitian ini berjumlah empat orang, yang terdiri dari dua orang pegawai yang bertanggung jawab terhadap pengelolaan aplikasi e-Visum pada Direktorat Teknologi Informasi dan Dokumentasi BKKBN (MA dan ZT), satu orang pegawai dari Direktorat Bina Lini Lapangan selaku pembina para penyuluh KB (DM), serta satu orang penyuluh KB (RS).

Selain itu, peneliti juga menggunakan data sekunder berupa data laporan pengisian eVisum oleh penyuluh KB untuk menganalisis tingkat pemanfaatan aplikasi e-Visum oleh para penyuluh tersebut. Penelitian menggunakan data laporan pengisian aplikasi e-Visum yang telah diolah oleh Direktorat Bina Lini Lapangan BKKBN, dari bulan Januari sampai dengan September 2018. Aplikasi e-Visum secara resmi digunakan sejak tanggal 1 Januari 2018 sehingga peneliti mengambil data dari bulan Januari sampai dengan September 2018. Tujuannya adalah untuk melihat tingkat adaptasi penyuluh $\mathrm{KB}$ dalam memanfaatkan sebuah inovasi baru (pelaporan kinerja online e-Visum) pada saat aplikasi tersebut mulai resmi digunakan. 


\section{HASIL DAN PEMBAHASAN}

Aplikasi e-Visum merupakan bagian dari pelaksanaan konsep e-government. Dengan dibangunnya aplikasi kinerja mobile ini, para penyuluh KB yang tersebar di desa-desa dapat dengan mudah melaporkan kegiatan yang dilakukannya setiap hari dan melaporkan lokasi kerjanya secara real time melalui fasilitas smartphone android yang dimilikinya. Sebelumnya, para penyuluh KB harus membuat laporan secara manual dan menyampaikannya ke Dinas KB kabupaten atau kota yang lokasinya jauh dari wilayah kerjanya. Dengan adanya pelaporan kinerja mobile, laporan kinerja harian penyuluh $\mathrm{KB}$ langsung diterima oleh admin kepegawaian BKKBN Pusat di Jakarta. Tentunya hal ini sejalan dengan konsep e-government yang bertujuan untuk meningkatkan efektivitas dan efisiensi pengelolaan program maupun operasionalisasi organisasi (Chen et al, 2008). Penggunaan aplikasi ini juga memangkas proses birokrasi pelaporan kinerja berjenjang yang sebelumnya harus disampaikan ke Dinas KB kabupaten/kota, lalu diteruskan ke Perwakilan BKKBN Provinsi setempat, baru kemudian dikirimkan ke Biro Kepegawaian BKKBN Pusat.

Berdasarkan hasil wawancara dengan ZT dan DM, diketahui bahwa aplikasi e-Visum dibangun dengan tujuan untuk mempermudah pemantauan kinerja para penyuluh $\mathrm{KB}$ yang tersebar di seluruh Indonesia. Dalam pembuatan aplikasi e-Visum, BKKBN bekerja sama dengan pihak ketiga yaitu pihak pengembang aplikasi atau vendor yang telah memenuhi kualifikasi yang ditentukan. Dengan adanya keterbatasan tenaga pranata komputer yang dimiliki dan banyaknya aplikasi yang sedang dikembangkan BKKBN dalam mendukung percepatan konsep $e$ - government, maka untuk merealisasikan aplikasi e-Visum, BKKBN melibatkan pihak ketiga selaku pengembang sistem. Pihak ketiga juga bertanggung jawab terhadap pemeliharaan dan pengembangan aplikasi eVisum.

Data yang dimasukkan oleh penyuluh KB melalui aplikasi e-Visum merupakan data digital. Data digital e-Visum juga dapat dikategorikan sebagai big data karena memiliki ukuran (volume, dimensi, dan kecepatan), keseragaman dan kompleksitas yang besar. Berdasarkan karakteristiknya, data digital mudah digandakan dan ditransmisikan dengan cepat serta cenderung bertambah banyak ketika dipindahkan ke perangkat penyimpanan yang berbeda, dikelola dalam versi yang berbeda, dan disimpan di berbagai lokasi. Jika data dibiarkan tidak terlindungi, file-file digital sangat mudah untuk dibaca dan dibajak orang lain. Terlebih, data e-Visum disimpan dalam server cloud. Komputasi cloud telah mengubah cara komputasi dengan menyediakan akses di mana-mana sesuai permintaan ke sumber daya komputasi (Irion, 2012). Menurut Irion (2012), teknologi cloud menjadi platform yang dapat mendorong terciptanya pemerintahan yang terbuka, kerja sama antarlembaga, dan inovasi pemerintah. Namun, teknologi cloud menimbulkan tantangan yang lebih mendasar bagi sektor publik dibandingkan dengan manajemen TI tradisional karena cloud membawa tata kelola informasi ke tingkat abstraksi yang baru (Petersen et al, 2011). Penyimpanan melalui cloud ini juga tetap memiliki kemungkinan terjadinya crash data, sehingga harus diupayakan untuk selalu disandikan dengan benar supaya aman dari peretas (Van Baalen, 2018). 
Akses ke server cloud pada aplikasi eVisum dimiliki oleh BKKBN dan pihak ketiga. Oleh karena itu, faktor keamanan data harus menjadi pertimbangan. Kerahasiaan data juga menjadi hal yang sangat penting karena kerahasiaan data organisasi pemerintahan dapat berimplikasi tidak langsung terhadap kerahasiaan dan kedaulatan negara, seperti pada kasus Edward Snowden yang membocorkan dokumen rahasia Amerika Serikat ke jurnalis asing. Menurut Nugraha et. al. (2015), metode paling mudah untuk memastikan kerahasiaan data adalah dengan menyandikan semua data sensitif pada proses penyimpanan, pemrosesan, dan transmisi. Masalah kepemilikan, akses dan kontrol atas penggunaan data juga masih menjadi isu penting dalam tata kelola pemerintahan (Bruhn, 2014). Dalam hal ini, BKKBN telah mengantisipasinya dengan proses pemilihan pengembang aplikasi (apps developer) sesuai dengan kriteria dan mekanisme yang transparan dan akuntabel. Selain itu, BKKBN juga membuat ketentuan yang mengikat dengan pihak pengembang mengenai aturan penggunaan, penyimpanan, dan kerahasiaan data serta menuangkan semua aturan dan kesepakatan tersebut dalam klausul perjanjian kontrak pengadaan e-Visum dengan pihak ketiga. Menurut informan MA, pada bulan awal penerapan e-Visum, beberapa kali terjadi kendala dalam sistem dan e-Visum sempat dihentikan selama beberapa jam untuk perbaikan. Data dalam e-Visum menjadi sangat penting karena di dalamnya terdapat rekap harian kegiatan yang berimplikasi pada pengukuran kinerja tiap penyuluh KB. Ukuran kinerja tersebut menjadi dasar penghitungan besaran tunjangan kinerja yang mereka peroleh tiap bulan. Untuk itu, pihak ketiga harus mampu menjamin keamanan dan keakuratan sistem e-Visum. Terlebih penyuluh KB diminta untuk memasukkan target sasaran dalam bentuk peta keluarga, yang diintegrasikan dengan hasil Pemutakhiran Pendataan Keluarga yang harus dijamin kerahasiaannya.

Berdasarkan data SIMSDM (Sistem Informasi Manajemen Sumber Daya Manusia) Biro Kepegawaian BKKBN per tanggal 1 Oktober 2018, jumlah tenaga penyuluh KB yang tersebar di seluruh Indonesia ada sebanyak 14.758 orang, dengan persebaran jumlah tertinggi berada di Provinsi Jawa Timur, Jawa Tengah, Sulawesi Selatan kemudian Jawa Barat. Jika dilihat dari jenis kelamin, jumlah tenaga penyuluh $\mathrm{KB}$ yang berjenis kelamin laki-laki ada 6.422 orang, sedangkan Penyuluh KB perempuan sebanyak 8.336 orang. Penelitian ini juga menggunakan data laporan pengisian aplikasi e-Visum oleh tenaga penyuluh $\mathrm{KB}$, yang telah diolah oleh Direktorat Bina Lini Lapangan BKKBN pada bulan Januari, Juni dan September 2018 (seperti pada Tabel 1). Peneliti melakukan analisis terhadap data pengisian e-Visum menggunakan teori difusi inovasi untuk melihat tingkat adopsi penyuluh KB dalam memanfaatkan aplikasi pelaporan kinerja mobile e-Visum.

Tabel 1. Persentase Capaian Kinerja Penyuluh KB melalui e-Visum per Provinsi (bulan Januari, Juni, September 2018)

\begin{tabular}{lccc}
\hline \multicolumn{1}{c}{ Provinsi } & Jan & Juni & Sept \\
\hline Aceh & 63 & 66 & 68 \\
Sumatera Utara & 78 & 79 & 89 \\
Sumatera Barat & 69 & 75 & 83 \\
Sumatera Selatan & 77 & 82 & 87 \\
Riau & 70 & 82 & 75 \\
Jambi & 75 & 64 & 69 \\
Bengkulu & 77 & 73 & 74
\end{tabular}




\begin{tabular}{|c|c|c|c|}
\hline Lampung & 60 & 74 & 89 \\
\hline Bangka Belitung & 89 & 86 & 94 \\
\hline Kepulauan Riau & 87 & 92 & 93 \\
\hline Jawa Barat & 80 & 81 & 88 \\
\hline Jawa Tengah & 89 & 86 & 88 \\
\hline Jawa Timur & 90 & 88 & 93 \\
\hline D.I.Yogyakarta & 89 & 83 & 91 \\
\hline Banten & 54 & 58 & 73 \\
\hline Bali & 84 & 84 & 91 \\
\hline NTB & 89 & 83 & 88 \\
\hline NTT & 41 & 46 & 67 \\
\hline Kalimantan Barat & 49 & 56 & 56 \\
\hline Kalimantan Selatan & 83 & 83 & 83 \\
\hline Kalimantan Tengah & 56 & 69 & 72 \\
\hline Kalimantan Timur & 65 & 63 & 72 \\
\hline Sulawesi Utara & 30 & 51 & 59 \\
\hline Sulawesi Selatan & 81 & 70 & 80 \\
\hline Sulawesi Tenggara & 71 & 80 & 77 \\
\hline Sulawesi Tengah & 54 & 70 & 59 \\
\hline Sulawesi Barat & 52 & 61 & 68 \\
\hline Gorontalo & 63 & 79 & 90 \\
\hline Maluku & 49 & 48 & 59 \\
\hline Maluku Utara & 30 & 38 & 46 \\
\hline Papua & 28 & 36 & 46 \\
\hline Papua Barat & 3 & 28 & 36 \\
\hline Rata-rata Capaian & 64,8 & 69,2 & 75,09 \\
\hline
\end{tabular}

(Sumber: Data Direktorat Bina Lini Lapangan, BKKBN, 2018)

Berdasarkan data laporan kinerja para penyuluh KB selama bulan Januari sampai dengan September 2018 (Tabel 1), terlihat bahwa pada rata-rata capaian kinerja para penyuluh $\mathrm{KB}$ pada bulan Januari adalah sebesar 64,8\%, bulan Juni 69,2\% dan pada bulan September 75,09\%. Nilai persentase itu didapat dari jumlah pengisian kegiatan harian penyuluh KB yang harus dimasukkan melalui e-Visum, baik kegiatan penyuluhan maupun nonpenyuluhan sesuai target yang telah ditentukan. Angka pada Tabel 1 menunjukkan adanya peningkatan capaian kinerja penyuluh

KB berdasarkan aplikasi e-Visum. Ini menjelaskan adanya perkembangan tahapan pengambilan keputusan dalam menerima dan mengadopsi sebuah inovasi atau teknologi baru. Sesuai dengan teori difusi inovasi, lamanya waktu adopsi merupakan hal yang penting dalam proses adopsi inovasi. Tingkat adopsi akan semakin meningkat seiring dengan waktu.

Dalam Tabel 1 juga terlihat bahwa tingkat adopsi untuk tiap-tiap provinsi berbeda-beda. Ini menjelaskan bahwa tiap individu memiliki kecepatan yang tidak sama dalam mengadopsi sebuah inovasi. Provinsi yang menunjukkan laporan kinerja di atas $90 \%$ pada bulan Januari 2018 hanyalah Provinsi Jawa Timur, sedangkan pada bulan September 2018 jumlah pengadopsi aplikasi ini bertambah menjadi Provinsi Bangka Belitung, Kepulauan Riau, Jawa Timur, D.I. Yogyakarta, Bali dan Gorontalo. Dari data tersebut, Provinsi Jawa Timur dapat dikatakan sebagai inovator, yaitu sebuah daerah dengan tingkat penerimaan yang tinggi terhadap suatu inovasi baru. Ini berarti bahwa para penyuluh KB Jawa Timur lebih mudah mengadopsi sebuah inovasi teknologi baru. Daerah perkotaan dan metropolitan memiliki kecenderungan tingkat adopsi inovasi yang lebih tinggi karena telah terbiasa menggunakan teknologi dalam kehidupan sehari-hari. Adapun provinsi yang memiliki laporan kinerja di bawah 50\% pada bulan Januari 2018 adalah Provinsi Nusa Tenggara Timur, Kalimantan Barat, Sulawesi Utara, Maluku, Maluku Utara, Papua, dan Papua Barat. Pada bulan September 2018, Provinsi Papua, Papua Barat dan Maluku Utara masih menjadi provinsi dengan laporan kinerja di bawah 50\%. Berdasarkan Tabel 1, Provinsi Papua, Papua Barat dan Maluku Utara masuk 
dalam kategori sebagai daerah dengan tingkat adopsi inovasi terendah yaitu kategori lamban (laggards). Provinsi maju dengan tingkat paparan media yang besar cenderung memiliki tingkat penerimaan terhadap inovasi aplikasi e-Visum yang lebih baik.

Tabel 1 juga menunjukkan bahwa tingkat adopsi aplikasi e-Visum oleh penyuluh $\mathrm{KB}$ dapat dikatakan cukup tinggi dengan ratarata capaian kinerja $64,8 \%$ pada bulan pertama penerapan e-Visum. Padahal, dari total 14.758 orang penyuluh KB, sebanyak 7.267 orang berasal dari generasi baby boomers (berusia lebih dari 51 tahun) dan 2.571 orang berusia 46-50 tahun. Generasi yang berjumlah sebanyak $66,7 \%$ dari total penyuluh $\mathrm{KB}$ tersebut cenderung lebih lambat dalam menerima teknologi digital jika dibandingkan dengan generasi milenial. Hal ini menunjukkan bahwa mereka mampu menerima dan mengadopsi teknologi e-Visum.

Selain itu, sebelum dipergunakan secara resmi per tanggal 1 Januari 2018, aplikasi eVisum juga telah diujicobakan selama dua bulan sebelumnya. BKKBN gencar menyosialisasikan cara penggunaan e-Visum secara bertahap di seluruh provinsi sejak satu tahun sebelumnya, baik secara konvensional melalui workshop dan pelatihan bertahap, maupun secara digital melalui informasi, tutorial, maupun live streaming e-Visum di akun media sosial Instagram @ rumahbacapkb, @bkkbnofficial, akun Facebook Rumah Baca PKB/PLKB, maupun grup WhatsApp. Dengan demikian, ada waktu yang cukup bagi para penyuluh KB untuk mempelajari dan beradaptasi dengan sistem pelaporan kinerja mobile ini sebelum akhirnya diterapkan secara resmi.

Tingkat adaptasi dipengaruhi oleh karakteristik inovasi, yaitu keuntungan relatif, kesesuaian, kompleksitas, trialability dan observability (Rogers, 2003). Pertama, semakin besar keuntungan yang diperoleh, maka semakin tinggi pula dorongan untuk mengadopsi inovasi tertentu. Adanya keuntungan materiel yang diperoleh penyuluh KB menjadi faktor pendorong adopsi e-Visum karena kinerja harian yang dicatat melalui aplikasi e-Visum ini berimplikasi langsung terhadap pengukuran besaran tunjangan kinerja yang diperoleh. Penyuluh KB akan mendapatkan jumlah tunjangan kinerja sesuai dengan besaran persentase pengisian kinerja yang ada di aplikasi e-Visum. Jika persentase capaian kinerja yang tercatat dalam aplikasi eVisum kecil, maka tunjangan kinerja yang diperolehnya juga sedikit, begitu pula sebaliknya. Kedua, aplikasi e-Visum telah mendukung karakteristik kesesuaian dalam teori difusi inovasi. Artinya, aplikasi e-Visum tidak bertentangan dengan nilai-nilai normatif di masyarakat sehingga tidak ada hambatan bagi seseorang untuk mengadopsi aplikasi eVisum. Ketiga, terkait dengan kompleksitas atau kerumitan. Aplikasi e-Visum memiliki tingkat kompleksitas yang cukup rumit, karena harus memasukkan data-data yang cukup detail, termasuk data keluarga dan lokasi titik koordinat pelaksanaan sebuah kegiatan. Namun, BKKBN telah mengantisipasinya dengan sosialisasi bertahap sejak satu tahun sebelumnya, serta adanya masa uji coba aplikasi e-Visum dua bulan sejak resmi digunakan. Keempat, aplikasi e-Visum memiliki kemampuan diujicobakan. Sebelum diterapkan secara resmi, e-Visum telah diuji coba selama dua bulan terlebih dahulu kepada para penyuluh $\mathrm{KB}$, sehingga dapat diketahui apa saja kekurangan sistem e-Visum yang harus segera diperbaiki. Terakhir adalah observability. Observability ini dapat ditinjau 
dari perspektif BKKBN selaku pengelola eVisum dan penyuluh $\mathrm{KB}$ selaku pengguna aplikasi tersebut.

Selama masa uji coba dan penerapannya, BKKBN telah mengamati tingkat keberhasilan e-Visum dan terus melakukan penyempurnaan seiring waktu. Menurut MA, e-Visum yang diluncurkan saat ini merupakan e-Visum versi 3.0, yang merupakan pengembangan dari versi awal 2.0 dengan tampilan yang lebih menarik dan mudah digunakan.

Di samping itu, terdapat pula penambahan beberapa fitur penunjang lain seperti fitur cuti, fitur bantuan dan notifikasi untuk menginformasikan status sinkronisasi kegiatan para penyuluh KB. Adapun dari perspektif penyuluh $\mathrm{KB}$, selama penerapan aplikasi e-Visum, mereka dapat mengamati tingkat penggunaan e-Visum dan kendala yang dihadapi tiap penyuluh di berbagai daerah melalui forum-forum diskusi di media sosial yang digunakan sebagai media sosialisasi BKKBN. Dengan berbagai karakteristik inovasi yang ada pada aplikasi e-Visum, tidak ada kendala berarti yang dapat menghambat adopsi penyuluh $\mathrm{KB}$ dalam menggunakan aplikasi ini sehingga tingkat adopsinya terlihat relatif semakin meningkat seiring berjalannya waktu.

Penerapan e-Visum ini juga bukanlah tanpa kendala. Menurut DM, pada awalnya banyak penyuluh KB yang melayangkan protes terhadap kebijakan penerapan laporan kinerja mobile ini. Hal ini terutama dialami para penyuluh $\mathrm{KB}$ yang wilayah kerjanya di desa terpencil, tidak terbiasa menggunakan smartphone android, serta memiliki kendala infrastruktur jaringan di beberapa lokasi yang kurang baik. Akan tetapi, sebuah sistem yang baik harus tetap dilanjutkan dan para pihak yang terlibat di dalamnya harus mampu menyesuaikan diri dengan perubahan yang ada.

\section{KESIMPULAN DAN SARAN}

Keterlibatan pihak ketiga pada pengembangan aplikasi e-Visum dinilai mampu mempercepat realisasi pembuatan dan penerapan aplikasi pelaporan kinerja di BKKBN di tengah keterbatasan sumber daya internal. Dengan adanya e-Visum, para penyuluh $\mathrm{KB}$ yang tersebar di desa-desa di Indonesia dapat melaporkan kegiatan hariannya dengan lebih mudah, efektif, dan efisien. BKKBN Pusat juga mudah memantau kinerja penyuluhnya di lapangan. Namun, keterlibatan pihak ketiga dalam pengembangan aplikasi e-Visum berdampak pula pada faktor keamanan dan kerahasiaan data. Data e-Visum manjadi sangat penting karena berisi rekap harian kegiatan penyuluh $\mathrm{KB}$ beserta input data keluarga dalam bentuk peta keluarga di wilayah kerja penyuluh KB yang harus dijamin keamanan dan kerahasiaan datanya. Penyimpanan data dalam bentuk data digital pada server cloud harus selalu disandikan dengan benar supaya aman dari pembajakan oleh orang yang tidak bertanggung jawab, terlebih dengan akses yang juga dimiliki oleh pihak ketiga. Kerahasiaan dan keamanan data lembaga pemerintah ini menjadi sebuah hal yang penting karena dapat berimplikasi tidak langsung terhadap kedaulatan negara.

Tingkat adopsi e-Visum oleh penyuluh KB tergolong baik, dilihat dari rata-rata capaian kinerja pada awal penggunaan sebesar $64,8 \%$ (bulan Januari 2018), yang kemudian meningkat menjadi $75,09 \%$ pada bulan September 2018. Hal ini menjelaskan adanya proses perkembangan tahap pengambilan keputusan dalam menerima sebuah inovasi. Sesuai dengan teori difusi inovasi, tingkat 
adopsi berbanding lurus dengan waktu. Sebelum akhirnya diterapkan secara resmi, aplikasi e-Visum ini telah diujicobakan selama dua bulan sebelumnya sehingga ada waktu yang cukup bagi para penyuluh $\mathrm{KB}$ yang $66,7 \%$ di antaranya berusia di atas 45 tahun untuk mempelajari penggunaan aplikasi eVisum. Faktor keterkaitan pengisian e-Visum dengan keuntungan relatif berupa tunjangan kinerja juga menjadi pendorong bagi para penyuluh $\mathrm{KB}$ untuk cepat mengadopsi dan menggunakan e-Visum. Tingkat adopsi untuk tiap provinsi juga berbeda-beda karena tiap individu dalam sebuah sistem sosial memiliki kecepatan yang tidak sama dalam mengadopsi inovasi. Berdasarkan tingkat kecepatan adopsinya, Provinsi Jawa Timur masuk dalam kategori inovator, sedangkan Provinsi Maluku Utara, Papua dan Papua Barat masuk ke dalam kategori lamban (laggard) dalam menerima sebuah inovasi teknologi baru.

\section{DAFTAR PUSTAKA}

BKKBN. (2017). Peraturan Kepala BKKBN Nomor 22 Tahun 2017 dan Petunjuk Teknis Pelaksanaan e-Visum.

Bruhn, J. (2014). Identifying useful approaches to the governance of indigenous data. The International Indigenous Policy Journal, 5(2), 1-32.

Checkland, P., \& Howell, S. (1998). Information, Systems and Information Systems: Making Sense of the Field. West Sussex, England: John Wiley and Sons Ltd.

Chen, et al. (2008). Digital Government: EGovernment Research, Case Studies, and Implementations. New York: Springer.

Ginige, T, \& Richards, D. (2012). A Model for Enhancing Empowerment in Farmers using Mobile Based Information System. $23^{\text {rd }}$ Australasian Conference on Information Systems. Geelong.

Clare, C. P., \& Loucopoulos, P. (1987). Business Information Systems. London: Paradigm.

Irion, K. (2012). Government Cloud Computing and National Data Sovereignty. Policy \& Internet, 4(3), 4071.

Kamal, M. M. (2006). IT innovation adoption in the government sector: identifying the critical success factors. Journal of Enterprise Information Management, 19(2), 192-222. https://doi.org/10.1108/17410390610645 085

Kemp, S. (2019). Digital 2019: Indonesia. Available from: https://datareportal.com/reports/digital2019-indonesia.

Keserwani, H. (2015). App Abuses: A Study of Increasing Risk in Users Adoption of Free Third-Party Mobile Apps in India. SIBM Pune Research Journal, X, 53-58.

Langridge, D. (2007). Phenomenological Psychology: Theory, Research and Method. The SAGE Handbook of Qualitative Research in Psychology. Harlow, England: Pearson Education Limited.

https://doi.org/10.4135/9781848607927. $\mathrm{n} 10$

Lehmann, K. (2007). Innovation Diffusion Theory: Rogers and Bass Model Discussion. Berlin: Humbolt Universitat Berlin.

Meranti, \& Irwansyah. (2018). Kajian Humas Digital: Transformasi dan kontribusi Industri 4.0 pada Stratejik Kehumasan. Jurnal Teknologi Informasi Dan 
Komunikasi, $\quad 7(1), \quad 27-36$.

https://doi.org/10.2527/jas2012-5761

Neuman, W. L. (2014). Social Research

Methods: Qualitative and Quantitative

Approaches. Pearson Education Limited

(Vol.

7).

https://doi.org/10.2307/3211488

Nugraha, Y., Kautsarina, Sastrosubroto, A. S. (2015). Towards Data Sovereignty in Cyberspace. 3rd International Conference on Information and Communication Technology, 465-471.

Petersen, Zachary N. J., Gondree, M., \& Beverly, R. (2011). A Position Paper on Data Sovereignty: The Importance of Geolocating Data in the Cloud. Proceedings of HotCloud 2011 [Online]. http://znjp.com/papers/petersonhotcloud11.pdf.

Putra, R. M. D. (2018). Inovasi Pelayanan Publik Di Era Disrupsi (Studi Tentang Keberlanjutan Inovasi E-Health di Kota Surabaya). 1-13. Retrieved from http://repository.unair.ac.id/id/eprint/746 54

Rao, R. (2011). e-Choupal transforms Indian agriculture. Appropriate Technology, 38(4).

Riedel, M. (2000). Research Strategies for Secondary Data: A Perpective for
Criminology and Criminal Justice. Thousand Oaks: Sage Publication Inc.

Rogers, E, M. (2003). Diffusion of Innovations, $5^{\text {th }}$ edition. New York: Free Press.

Strauss, A., \& Corbin, J. (1990). Basics of qualitative research: Grounded theory procedures and techniques. Newbury Park, CA: Sage.

Thulin, E., \& Vilhelmson, B. (2007). Mobiles everywhere. Young, 15(3), 235-253. https://doi.org/10.1177/11033088070150 0302

Tuli, F. (2010). The Basis of Distinction Between Qualitative and Quantitative Research in Social Science: Reflection on Ontological, Epistemological and Methodological Perspectives. Ethiopia Jurnal of Education \& Science, 6(1), 97108.

Ulin, P. R., Robinson, E. T., \& Tolley, E. E. (2004). Qualitative Methods in Public Health: a Field Guide for Applied Research. San Fransisco: Jossey Bass.

Van Baalen, S. (2018). 'Google wants to know your location': The ethical challenges of fieldwork in the digital age. Research Ethics, 1-17. https://doi.org/10.1177/17470161177503 12 